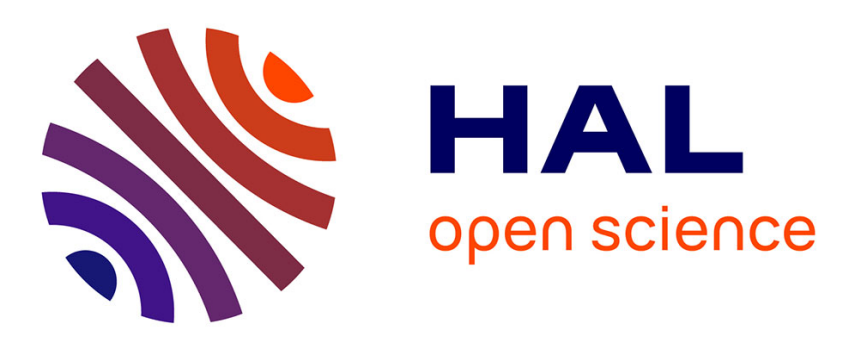

\title{
Release of ferulic acid from maize bran and derived oligosaccharides by Aspergillus niger esterases
}

\author{
C.B. Faulds, P.A. Kroon, L. Saulnier, J.F. Thibault, G. Williamson
}

\section{To cite this version:}

C.B. Faulds, P.A. Kroon, L. Saulnier, J.F. Thibault, G. Williamson. Release of ferulic acid from maize bran and derived oligosaccharides by Aspergillus niger esterases. Carbohydrate Polymers, 1995, 27 (3), pp.187-190. hal-02708815

\section{HAL Id: hal-02708815 https://hal.inrae.fr/hal-02708815}

Submitted on 1 Jun 2020

HAL is a multi-disciplinary open access archive for the deposit and dissemination of scientific research documents, whether they are published or not. The documents may come from teaching and research institutions in France or abroad, or from public or private research centers.
L'archive ouverte pluridisciplinaire HAL, est destinée au dépôt et à la diffusion de documents scientifiques de niveau recherche, publiés ou non, émanant des établissements d'enseignement et de recherche français ou étrangers, des laboratoires publics ou privés. 


\title{
Release of ferulic acid from maize bran and derived oligosaccharides by Aspergillus niger esterases
}

\author{
Craig B. Faulds ${ }^{a *}$, Paul A. Kroon ${ }^{\prime}$, Luc Saulnier", Jean-François Thibault ${ }^{b}$ \& Gary Williamson ${ }^{a}$ \\ "Department of Food Molecular Biochemistry, Institute of Food Research, Norwich Research Park, Colney, Nomrich, NR4 7UA, UK \\ "Institure National de la Recherches Agronomique, Laboratoire de Bioclimice et Technologic des Glucides, BP 527, 44026 Nantes, \\ France
}

(Received 6 November 1994; accepted 5 May 1995)

\begin{abstract}
We have examined two A. miger csterases (FAE-III (ferulic acid esterase III) and CinnAE (cinnamic acid csterasc)) for their ability to relcase ferulic acid from maize bran, a particularly rich source of ferulic acid. However, even though both cnzymes exhibited signilicant activites on novel leruloylated oligosalcharides derived from maize bran (including FAXX (O-(5-O-feruloyl- $\alpha-1$. -alrabinofuranosyl)-( $(\rightarrow 3)-O-\beta$-xylopyranosyl-( $(1 \rightarrow 4)$-D-xylopyranose)), neilher esterase wats efficient in removing ferulic acid from the whole bran, even in the presence of other carbohydrases. It is shown that the kinctics of ferulic acid relcase from feruloylated oligosaccharides wats influenced by (i) the nature of the sugiur-sugat linkage, and (b) the type of sugar present. The results suggest that enzymic release of ferulic acid from maize bran is limited by physical and steric factors, not by the chemical nature of the linkage.
\end{abstract}

\section{INTRODUCTION}

Ferulic acid is the most abundant hydroxycinnamic acid in the plant world, and as such, is a common constituent of animal fornge. It is linked to arabinose or galactosc residues in the pectic or hemicellulosic component of the cell walls of bamboo shoots, coastal bermuda grass, sugar cane bagalsse, barley straw, wheat bran, sugar beet pulp, spinach and maire (Ralph \& Helm, 1993).

Ferulic acid comprises $0.5 \%(\mathrm{w} / \mathrm{w})$ of whealt bran (Ralet el al., 1990), $0.8 \%$ of sugar beet pulp (Micard et a!., 1994) and 3.1\% of maize bran (Saulnier el al., 1995a). The removal of ferulic acid by enzymic methods would allow the exploitation of the acid for industrial and food applications (Gross-Falconnicr, 1991; Grar, 1992; Cheetham, 1993).

Efficient enzymic removal of ferulic acid from plant cell wall materials, such as wheat bran, has been shown to require the synergistic interaction between an esteratse and an endoxylimase (Faulds \& Williamson, 1991, 1993a, 1993b, 1994; Ferreira et al., 1993). Hydrolysis of more complex cell will matcrial, such as sugar beet pectin, involves cerlain specific esterases, and requires a larger battery of cell wall degrading enzymes (unpublished results). Aspergillus niger and Pseudomonas fluor-

* Author to whom correspondence should be addressed. escens esterases have also been shown to hydrolyse feruloylated oligosaccharides derived by acid hydrolysis from wheat bran and sugar beet pulp (Ralet et al. 1994; Faulds et al., 1995).

The ferulic acid content in maize bran is higher than that in cither wheat bran or in sugar beet pulp, but malize bran xylan is more highly substituted with xylose, arabinose and galactose residucs (Chanliaud et al., 1995; Satulnier ef at., 1995a). In this paper, we examine both the ability of an $A$. niger ferulic acid esterase (FAE-III; Faulds \& Williamson, 1994) and A. niger cinnamis acid cstcrase (Cinn $\mathrm{E}$; unpublished results) to release ferulic acid from maize bran with and without the addition of carbohydrates, and also the action of cinnamoyl esterases on two novel feruloylated oligosalceharides derived from maize bran (Saulnier 't al., 1995h).

\section{MATERIALS AND METHODS}

Plant material

Micronised maize brans werc provided by ULICE (France). Brans (100 g) were dispersed in distilled water (1 1), Termamyl $1201,(20 \mathrm{ml})$ added, and the mixture maintained in a boiling water bath for $60 \mathrm{~min}$. The 
residue was recovered by filtration on a glass sintered funnel, washed with water and dried by washing with ethanol, and then acctonc, beforc placing in an oven at $40^{\circ} \mathrm{C}$ for 24 h. $74 \mathrm{~g}$ was recovered. De-starched bran (10 mg) was treated with $1 \mathrm{M} \mathrm{NaOH}$ for $24 \mathrm{~h}$ (room temperature and in the dairk). The solubie fraction, after centrifugation at $9500 \mathrm{~g}$ for $5 \mathrm{~min}$, wats neutralised with 2 vol $1 \mathrm{M} \mathrm{HCl}$ and ferulic acid levels analysed by HPLC (Faulds \& Williamson, 1991), which indicated an alkaliextractable ferulic acil content in this preparation of $2.5 \%(w / w)$.

The feruloylated oligosaccharides, XAF $(O-\beta$-D)-xylopyranosc- $(1 \rightarrow 4)-O-\beta$-D-xylopyranosyl-( $(1 \rightarrow 2)-(5-O$ - - $c r u-$ loyl)- $\alpha$-L-arabinofuranosyl) and GXAF (O-Lgalactopyranose- $(1 \rightarrow 4)-O-(\beta$-D-xylopyranosyl- $(1 \rightarrow 2)-(5-$ $O$-feruloyl)- $\alpha$-L-arabinofuranoyl) (Fig. 1), were isolated from acid-hydrolysed maize bran and characterised as described previously (Salulnicr el al., 1995h).

\section{Enzymes}

Aspergillus niger FAE-111 was purified from oat spelt xylan-grown cultures of $A$. niger CBS 120.49, as described previously (Faulds \& Williamson, 1994). A. niger CinnAE was purified from sugar beet pulp-grown cultures of $A$. niger CSIS0 (unpublished results). CinnAE diflers from liAE-III in both physical properlics and substrate specilicities on model substrates and feruloylated oligosaccharides.

Drisclase, a basidiomyecte enzyme preparalion, was obtained from Sigmal Chemical Co., and purilied by the method of Borneman et al. (1990). The protein concentration of the purified mixture was $9.8 \mathrm{mg} / \mathrm{ml}$.

Endo- $\beta-1,4$-xylanase from Trichoderma viride and $\alpha$ L-arabinofuranosidase from $A$. niger were purchased from Megazyme (Aust) Pty Ltd.

One unit (U) of enzyme activity is expressed as the amount of cnzyme releasing $1 / \mu \mathrm{mol}$ of product $/ \mathrm{min}$ under the given conditions. For the cinnamoyl esterases, these are $\mathrm{pH} 6.0$ and $37^{\circ} \mathrm{C}$.

\section{Assays}

Release of frec ferulic acid from de-starched maize bran (DSMB) was measured on reverse phase HPLC as previously described for de-starched wheat bran (Johnson et al., 1988), using $20 \mathrm{mg} D \mathrm{DSM} B / \mathrm{ml}$ assay. Relcase of free ferulic acid from the feruloylated oligosaceharides XAF and GXAF was measured speetrophotometrically at $335 \mathrm{~nm}$ by the method of Ralet et al. (1994), using extinction coefficients of 13,800 and $22,800 / \mathrm{M} / \mathrm{cm}$, for XAF and GXAF, respectively. $K_{\mathrm{m}}$ and $V_{\max }$ measurements were determined by the method of Wilkinson (1961), using 0-0.5 mM XAF and 0$0.3 \mathrm{mM} \mathrm{GXAF}$, and $5 \mathrm{mU}$ FAE-III or $6.1 \mathrm{mU}$ CinnAE. Protein was determined using the Coomassic Protein Assay Reagent from Pierce.

\section{RESULTS AND DISCUSSION}

\section{Hydrolysis of de-starclied maize bran}

No ferulic acid was detected when CinnAE $(33 \mathrm{mU})$ was incubated with DSM B, even after 24 h. $0.3 \%$ of the total level of Perulic acid wals released when FAE-lll $(13 \mathrm{mU})$ was used. This level is very low, corresponding to $66 \mu \mathrm{g}$ ferulic acid per gram maize bran compared to $30 \mu \mathrm{g}$ lerulic acid per gram wheat bran $(0.6 \%)$ in only 30 min by the same amount of the same enzyme (Faulds \& Williamson, 1994), which increased to $4 \%$ after $24 \mathrm{~h}$ (200 ug per gram wheat bran; unpublished results). The complex nature of the maize bran (Saulnier ef al., 1995a) may thus limit the accessibility of the esterases to the feruloylated regions.

To fucilitate hydrolysis, $T$. viride endoxylanase $(0.02-$ $2 U$ ), or T. viride endoxylanasse ( $1 U$ ) and $A$. niger $\alpha-1$ arabinofuranosidase $(0.03-2 \mathrm{U})$, was added to the DSMB/FAE-III assay. In the presence of xylamasc, FAE-III was able to increase the amount of ferulic acid released from 0.26 to $0.6 \%$. The presence of $\alpha$-allabinofuranosidase failed to increase the amount of free acid released, suggesting more complex carbohydratedegrading enzymes were required. One such complex mixture, Driselase, was thus used in conjunction with FAE-III or CinnAE. After $24 \mathrm{~h}$, with the addition of $1 \mathrm{mg}$ purilied Drisclasc, $\mathrm{FAE}-11 \mathrm{l}(26 \mathrm{mU})$ releilsed $2.3 \%$ of the ferulic acid from DSMB, and CinnAE $(3.3 \mathrm{mU})$ relualsed $0.93 \%$.

Thus, the esterases were able to release a small anount of ferulic acid after limited hydrolysis of DSMB. Onc possible explanation could be due to the number of substitutions on the heteroxylan backbone on maize, the presence of highly branched xylose in the side-chitin, and the presence of a linkage between arabinose and xylose near the ferulic acid group. Vietor and co-workcrs (1994) found that with barley arabinoxylans, the presence of 2 O-Ara, $-\mathrm{Xyl}_{\text {, }}$ appeared to block the action of Aspergillts. awamori endoxylanase I, leading to lower degradation of barley arabinoxylans when compared to wheal arabinoxylans (Gruppen et al., 1992). Thus, with maize bran hetcroxylans, the endoxylaniss and accessory enzymes present in Drisclase may be blocked by the linkalges and substitutions present on the backbone, and FAE-III can only act on easily accessible regions. This difference in linkage between wheat bran, and maize bran maly also explain why $T$. viride endoxylanase has no elfect on ferulic acid release, but has a big effect on wheat bran when in conjunction with $A$. niger FAE-III (Faudels \& Williamson, 1994).

Driselase was found to relcase approximately $45 \%$ of solubilised feruloyl groups from maize shoots as FAXX $(O-(5-O$-feruloyl)- $\alpha$-L-arabinofuranosyl)-( $(1 \rightarrow 3)-O-\beta$-xylopyranosyl-(1 $\rightarrow 4)$-D-xylopyranose: Kato \& Nevins, 1985), only alter preliminary hydrolysis of the maize with $30 \mathrm{~mm}$ oxalic acid followed by a long $(120 \mathrm{~h})$ 
incubation of the insoluble bran with Driselase. The remaining $55 \%$ remained uncharacterised. This suggests that the oxalic acid hydrolysed the maize sufficiently for the Driselase to slowly break up the remaining polymer. However, this level of hydrolysis has not so far been achieved using enzymes alone.

\section{Hydrolysis of feruloylated oligomers}

As the relcase of ferulic acid from intact maize bran was limited, the basis for the poor hydrolysis was examined. We tested whether it was due to the nature of the ester linkage or to steric and physical factors in the maize cell wall. The nature of the ester linkage between ferulic acid and the sugar has previously been shown to influence hydrolysis of feruloylated oligosaccharides derived from wheat bran and sugar beet pulp (Ralet et al., 1994; unpublished results). The ability of these two fungal cnzymes to hydrolyse feruloylated compounds identilied in maize bran, such as Ara, F (5-O-feruloyl- $\alpha$-L-arabinofuranose; Saulnier et al., 1995b) and FAXX (Ohta et al., 1995; Kato \& Nevins, 1985) has previously been demonstrated (Ralet el al., 1994; unpublished results). However, their ability to hydrolyse two novel feruloylated oligosaccharides from maize bran, XAF and GXAF, has not been determined.

XAF and GXAF werc isolated by acid hydrolysis and gel filtration chromatography (Saulnicr et al., 1995b), and their structures are shown in Fig. 1. FAXX constitutes $\sim 45 \%$ of the ferulic acids in maize shoot cell walls (Kato \& Nevins, 1985), while XAF, GXAF and Ara, F represent $\sim 33 \%$ in maize bran cell walls (Saulnier et al., 1995b). Wheat bran isolates corresponding to FAXX and $\mathrm{Ara}_{1} \mathrm{~F}$ were hydrolysed by both FAE-III (Ralet et al., 1994) or CinnAE (umpublished results). In XAF, $x y$ lose is $(1 \rightarrow 2)$ linked to the arabinose residuc, in contrast to wheat bran, where arabinose is linked $(1 \rightarrow 3)$ to xylose. Xylose is also present in the side-chains of maize xylans. Arabinose is the reducing sugar in maize, xylose the reducing sugar in wheat bran. Characterisattion of feruloylated oligosaccharides isolated from maize bran has shown the presence of galactose linked $(1 \rightarrow 4)$ to xylose residues (Saulnicr et al., 1995b). To datc, such a linkage has not becn found in wheat bran.
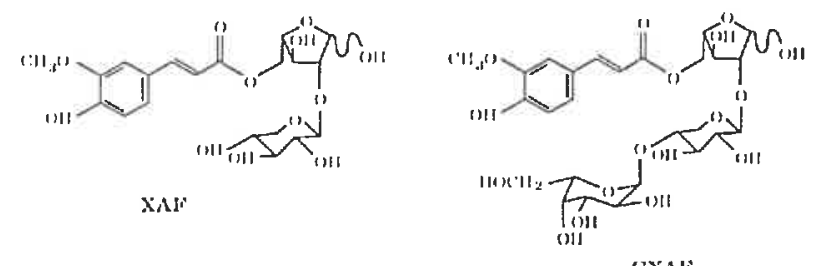

GXAF

Fig. 1. Suructures of two novel feruloylated oligosaccharides isolated from maize bran (from Saulnier et al, 1995b). XAF, $\left(O-\beta-\mathrm{D}-\mathrm{xyl}_{\rho}(1 \rightarrow 2)-[(5-O-(\right.$ (cruloyl)-L-Ara $)] ;$ GXAF, (O-L-Gal,$)-$ $(1 \rightarrow 4)-O-\beta-1)-\left.x y\right|_{j},-(1 \rightarrow 2)-\left(5-O-\left(f_{\text {eruloyl }}\right)-L-a r a l_{j}\right)$

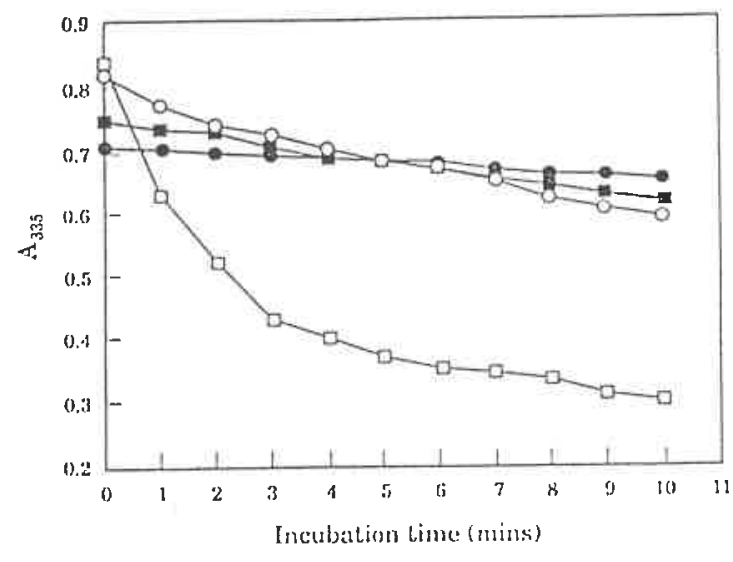

Fig. 2. Relcase of ferulic acid from XAF and GXAF (33 $\mu \mathrm{M})$ by $A$. niger esterases $(5 \mathrm{mU}) . \triangle A_{335}$ of 0.1 during $X A F$ and GXAF hydrolysis by the cstcrases corresponds to $22 \%$ and $13 \%$ hydrolysis, respectively, of the reicvant substrate. $\square$, XAF with FAE-III; XAF with CinnAE; O, GXAF with FAE-Ill; •, GXAF wilh CimnAE.

Figure 2 shows the rates of the reaction of $5 \mathrm{mU}$ of cither FAE-III or CinnAE on XAF and GXAF. The hydrolysis of XAF by FAE-III was rapid (initial rate $=93.0 \mathrm{U}$ per mg protein), with $52 \%$ of the total ferulic acid level being released within $4 \mathrm{~min}$. The rate of relcase of ferulic acid from the same substratc by CinnAE was 10-fold lower (0.77 U per mg prolein) with $4.8 \%$ hydrolysis in 4 min. Similarly, the activity of FAE-III on GXAF (23.8 U per mg protein: $11.8 \%$ hydrolysis in 4 min) was significantly higher than that found for CinnAE (0.40 $\mathrm{U} \mathrm{g}^{-1}$ and $3.1 \%$, respectively), but both enzymes demonstrated a preference for the feruloylated disaccharide.

Calculations of kinctic constants $\left(K_{\mathrm{n}}\right.$ and $\left.V_{\text {max }}\right)$ revealed that even though both enzymes had a higher catalytic elficiency on XAF, CinnAE had a grcatcl allinity for the disaccharide whercas FAE-III had at greater affinity for the trisaccharide (Table 1). Furthermore, the larger magnitude of difference observed in the catalytic efliciency between the two enzymes $(\sim 100$ fold) was due to the differences in $V_{\max }$ and not in the values for $K_{\mathrm{m}}$. It has been shown that the spectrophotometric activities on many other substrates common to both enzymes are much higher using FAEIII than with CinnAE, except in the case of $A$ ra, F from sugar beet (Faulds \& Williamson, 1994; Ralct et al., 1994; unpublished results).

A comparison of the catalytic elficiencies of FAE-IHI from this work and previously reported work on Ceruloylated oligosaccharides from wheal brain and sugarbect pulp (Ralet et al., 1994) reveals that the type of sugar ester-linked to ferulic acid clearly influences the ability of the enzyme to hydrolyse ferulic acid (Table 2). Ferulic acid is ester-linked to arabinose at $\mathrm{C}-5$ in maize bran, but the attachment of xylose to the $\mathrm{C}-2$ of arabinose reduces the efficiency compared to a $\mathrm{C}-3$ attach- 
Table 1. $K_{\mathrm{m}}$ and $V_{\max }$ values for the hydrolysis of XAF and GXAF from maize bran by $A$. niger FAE-III and CinnAE

\begin{tabular}{lcccc}
\hline & \multicolumn{2}{c}{ FAE-III } & \multicolumn{2}{c}{ CinnAE } \\
\hline Substratc & XAF & GXAF & XAF & GXAF \\
$K_{\operatorname{man}}(\mathrm{mM})$ & $0.383( \pm 0.08)$ & $0.162( \pm 0.02)$ & $0.125( \pm 0.01)$ & $0.223( \pm 0.04)$ \\
$V_{\max }(\mathrm{U} /$ mg prolein $)$ & $938( \pm 138)$ & $176( \pm 19)$ & $3.80( \pm 0.27)$ & $3.94( \pm 0.71)$ \\
Catalytic efficiency & 2448 & 1086 & 30.4 & 17.7 \\
$\left(V_{\text {max }} / K_{\mathrm{m}}\right)$ & & & & \\
\hline
\end{tabular}

Table 2. The catalytic efficiency of $A$. niger F $\Lambda E$-III for various feruloylated oligosaccharides

\begin{tabular}{lcc}
\hline Substratc & Nomenciature & $\begin{array}{c}\text { Catalylic } \\
\text { efficiency }\end{array}$ \\
\hline Substrate & MFA & 84 \\
Monosaccharide & GalF & 40 \\
& AraF & 1728 \\
Disaccharide & (AraFs-FA) & \\
Trisaccharide & XAF & 2448 \\
& GXAF & 1086 \\
Telrasaccharide & FAXX & 7600 \\
\hline
\end{tabular}

ment, as found in wheat bran. Whereas the presence of two xylose sugars increased the rate of hydrolysis of FAXX derived from wheat bran (also found in maize bran), solution of L-galactose for the terminal xylose reduced the catalytic efficiency 7 -fold.

From these results and from the work on wheat branderived oligosaccharides, we can conclude that: (a) the position of the ester linkage between Ierulic acid and the primary sugar; (b) the position of the linkage between the primary and sccondary sugars; (c) the length of the oligosaccharide; and (d) the type of sugars present, all influence the release of ferulic acid by $A$. niger FAE-III and CinnAE from plant cell wall material.

In summary, less than $1 \%$ of alkali-extractable ferulic acid was released from DSMB by two $A$. niger esterases. The presence of cirbohydrase mixtures only slightly increased this releasc. However, novel feruloylated oligosaccharides isolaled from maize bran were good substrates for the enzymes, suggesting steric and physical factors limit hydrolysis of the intact maize bran. The type of sugar and nature of sugar-sugar linkages also were found to strongly influence the rate of hydrolysis.

\section{ACKNOWLEDGEMENTS}

We are grateful to the BBSRC, INRA and the European Commission (AIR programme, Grant No. PL 920026) for funding.

\section{REFERENCES}

Borneman, W.S., Hartlcy, R.D., Himmelsbach, D.S. \& Ljungdahl, L.G. (1990). Analyt. Biochem., 190, 129-133.

Chanliaud, E., Saulnier, L. \& Thibault, J.-F. (1995). J. Cereal Sci., 21, 195-203.

Chcelham, P.S.J. (1993). TIBTECH, 11, 478-488.

Faulds, C.B., Raict, M.-C., Williamson, G., Hazlewood, G.P. \& Gilbert, H.J. (1995). Biochim. Biophys. Acta., 1243, 265-269.

Faulds, C.B. \& Williamson, G. (1991). J. Gen. Microbiol., 137, 2339-2345.

Faulds, C.B. \& Williamson, G. (1993a). Carbohydr. Polym., $21,153-155$.

Faulds, C.B. \& Williamson, G. (1993b). Biotec/mol. Appl. Biochem., 17, 349-359.

Faulds, C.B. \& Williamson, G. (1994). Microbiology, 140, $779-787$

Ferreira, L.M.A., Wood, T.M., Williamson, G., Faulds, C.B., Hazlewood, G.P. \& Gilbert, H.J. (1993). Biochem. J., 294, 349-355.

Graf, E. (1992). Free Rad. Biol. Med., 13, 435-448.

Gross-Falconnier, B. (1991). Thèse de troisème cycle, Universitc̀ de Paris-Sud centrc d'Orsay $131 \mathrm{pp}$.

Gruppen, H., Holfman, R.A., Kormelink, F.J.M., Voragen, A.G.J., Kamerling, J.P. \& Vliegenthart, J.F.G. (1992). Carbohydr. Res., 233, 45-64.

Johnson, K.G., Harrison, B.A., Schneider, H., MacKenzic, C.R. \& Fontana, J.D. (1988). Enzyme Microb. Tecluol., 10, 403-409.

Kato, Y. \& Nevins, D.J. (1985). Carbohydr. Res., 137, 139-150.

Micard, V., Renard, C.M.G.C. \& Thibaull, J-F. (1994). Lebensm.-Wiss. u-Teclinol., 27, 59-66.

Ohta, T., Yamasaki, S., Egashirc, Y. \& Sanada, H. (1994). J. Agric. Food Chem., 42, 653-656.

Ralel, M.-C., Faulds, C.B., Williamson, G. \& Thibaull, J.-F. (1994). Carbohydr. Res., 263, 257-269.

Ralct, M.-C., Thibault, J-F. \& Della Valle, G. (1990). J. Cereal. Sci., 11, 249-259.

Ralph, J. \& Helm, R. (1993). In Forage Cell Wall Structure and Digestibility, eds H.G. Jung, D.R. Buxton, R.D. Hatficld \& J. Ralph. ASA-CSSA-SSSA, Madison, USA, pp. 201-246.

Saulnier, L., Marol, C., Chanliaud, E. \& Thibanult, J.-F. (1995a). Carbohydr. P'olym., 26, 279--287.

Saulnier, L., Vigouroux, J. \& Thibault, J.-F. (1995b). Carbohydr. Res. 272, 241-253.

Viëlor, R.I., Holfman, R.A., Angelino, S.A.G.J.; Voragen, A.G.J., Kamerling, J.P. \& Vlicgenhart, J.F.G. (1994). Carbohydr. Res., 254, 245-255.

Wilkinson, G.N. (1961). Biochem. J., 80, 324-332. 